УДК 347.61/.64

DOI https://doi.org/10.32849/2663-5313/2019.10.08

\title{
Ольга Явор,
}

докт. юрид.наук,

професор кафедри цивільного права № 2

Начіонального юридчного університету імені Ярослава Мудрого

\section{«СІМЕЙНЕ ЖИТТЯ» В ІНТЕРПРЕТАЦІЇ ЄВРОПЕЙСЬКОГО СУДУ 3 ПРАВ ЛЮДИНИ}

У статті здійснено науково-теоретичний аналіз змісту поняття «сім'я» у юридичній науиі, представлено порівняльний аналіз поняття «сім'я» з урахуванням специфіки сімейно-шлюбних відносин. Автор вважає, що вирішення питання про належні стандарти врегулювання сімейних правовідносин не може відбуватися поза аналізом правових позицій Свропейського суду з прав людини. У своїй практииі Суд здебільшого виходить із розуміння поняття сім'ї у значенні «сімейне життя», яке обмежується core family. У статті зазначено, шо поняття сім'ї у значенні ст. 8 Конвениї включає в себе не тільки зареєстровані подружні відносини, але й інші «сімейні» зв'язки, які передбачають, що їх учасники живуть спільно поза законним шлюбом і в них теж виникають сімейні права й обов'язки, як і в зареєстрованому шлюбі. Автор на основі аналізу прецедентної практики Європейсъкого суду з прав людини виокремлює його основні правові позицї, що відіграють найбільш значущу роль у вирішенні справ, пов'язаних із застосуванням ст. 8 Конвенцї про захист прав і основоположних свобод. Автором зроблено висновок, що сучасне розуміння Конвениією поняття «сімейне життя» включає багатоаспектну конструкиію «сімейне життя», безумовно, враховуючи поняття «сім'я», найрізноманітніші суспільні процеси - від мігращї до новітніх медичних технологій. 3 урахуванням специфіки сімейних прав, гарантованих ст. 8 Конвениї, у врегулюванні юридичних фактів у сімейноправовій сфері мають враховуватися межі державного впливу на відносини, що складаються в сім'ї, а також дотримуватися баланс у нормуванні загально-правових відносин та приватних сімейних відносин особистого характеру, які взагалі не повинні регулюватися законом або мають піддаватися мінімальному нормативному впливу. Наведений аналіз дозволяє зробити висновки, що мають враховуватися для визначення основних напрямів розвитку начіональної правової системи у сфері правового регулювання сімейних відносин.

Ключові слова: сім'я, соціальне розуміння сім'ї, юридичне розуміння сім'ї, сімейне життя, сімейні зв’язки, позитивні зобов’язання держави, негативні зобов’язання держави.

Постановка проблеми. Сім'я як соціальне утворення виступає найважливішим елементом розвитку в усіх цивілізаціях [1, с. 10]. Вона є певною моделлю суспільства на конкретному історичному етапі його існування, відображує моральні і духовні особливості суспільства. Життя більшості людей так чи інакше пов'язано із сім'єю - своєрідним мікросвітом, де переплітаються складні економічні, політичні, психологічні, ідеологічні, фізіологічні та інші соціальні питання [2, с. 77]. Питання сімейних правовідносин завжди є об'єктом пильної уваги правознавців.

Аналіз досліджень і публікацій. У юридичній науці робилися численні спроби розкрити поняття «сім'я». Серед них - наукові доробки таких учених, як М. В. Антокольська, Ю. Ф. Беспалов, С. М. Білогорська, І І А. Бірюков, В. І. Бошко, Я. Р. Веберс, С. М. Ворожейкін, Л. І. Глушкова, П. П. Глущенко, В. Г. Голованов, В. С. Гопанчук, В. І. Данілін, Н. М. Єршова, І. В. Жилінкова, О. І. Заго- ровський, О. М. Калітенко, О. Ю. Косова, П. В. Крашенінніков, I. М. Кузнецова, Р. П. Мананкова, Г. К. Матвєєв, В. Ф. Маслов, С. О. Муратова, О. М. Нечаєва, О. М. Нємков, М. Т. Оридорога, Л. М. Пчелінцева, 3. В. Ромовська, В.О. Рясенцев, Г. М. Свердлов, С.Я. Фурса, Ю. С. Червоний, В. П. Шахматов, Я. М. Шевченко та інші.

Однак одностайності у поглядах щодо поняття «сім'я» вище названих науковців досягнуто не було. Це зумовлює необхідність розглянути поняття «сімейне життя» для того, щоб отримати повне і всебічне уявлення про сім'ю у сімейному праві.

Метою даної статті є науково-теоретичний аналіз поняття «сім'я», дослідження стану регулювання відносин щодо поняття «сімейне життя» в практиці Європейського суду з прав людини.

Виклад основного матеріалу. Людина, іiї життя та здоров'я є найвищими цінностями держави, а сім'я - основою, найважливішою 
складовою частиною, первинним та основним осередком суспільства. Велике значення інституту сім’ї робить їі предметом уваги багатьох наукових досліджень - соціологічних, педагогічних, правових тощо. Стаття 3 СК України визначає сутність поняття «сім'я» через три iї ознаки, котрі випливають із розуміння сім'ї як союзу двох чи більше осіб, а саме: спільне проживання; спільний побут; взаємні права та обов'язки. Більшість науковців вважають, що недоцільно надавати юридичне визначення поняттю «сім'я». Вони вважають, що у правознавстві має застосовуватися поняття «сім'я», яке розроблене наукою соціологією. Наведемо декілька визначень сім'ї, запропоновані соціологами.

Так, Г. Харчева зазначає, що сім’ю можна визначити як малу соціальну групу, що володіє історично визначеною організацією, члени якої пов'язані шлюбними чи родинними відносинами, спільністю побуту, взаємною моральною відповідальністю і соціальною необхідністю, яка зумовлена потребою суспільства у фізичному і духовному відтворенні населення [3, c. 57].

На думку М. Д. Шиміна, сім'я - це специфічна форма соціальної життєдіяльності людей, зумовлена економічним ладом суспільства, заснована на шлюбі чи родинності, включаючи всю сукупність відносин (між чоловіком і дружиною, батьками і дітьми, між різними поколіннями), що складаються на базі спільної різносторонньої діяльності їі членів, у якій реалізуються як потреби суспільства (у фізичному і духовному відтворенні людської особистості, в забезпеченні нормальної спільної життєдіяльності людей у сфері особистого життя), так і потреби індивіда (в інтимних зв'язках, у сімейному особистому щасті) [4, c. 21].

У юридичній науці закріпилася точка зору про наявність соціологічного та юридичного розуміння сім'ї. Одним із перших цю теорію обгрунтував В.О. Рясенцев, який зазначав, що існує загальне (соціологічне) і спеціальне (юридичне) поняття сім’ї, «в соціологічному розумінні сім'я є союзом осіб, що заснований на шлюбі, родинності (чи лише родинності), прийнятті дітей на виховання, що характеризується спільністю життя, інтересів, взаємною турботою» [5, с. 43]. Г. Ф. Шершеневич, вказуючи на наявність юридичного змісту в понятті сім’ї, визначав, що фізичний і моральний склад сім’ї складається поза правом, а юридичний елемент є необхідним і доцільним у сфері майнових відносин членів сім’ї. Сім'я є основною ланкою державного організму і користується деякою автономією [6, с. 406-407].

Заслуговує на підтримку позиція науковців, згідно з якою юридичне визначення сім’ї
$€$ необхідністю, оскільки переважна більшість галузей права України трактує сім'ю як правову категорію, піддаючи їі правовій регламентації, у зв'язку з чим сім'я не може не мати юридичного визначення. Ми підтримуємо точку зору В. А. Ватрас, що «сім'я - це юридичний зв'язок між фізичними особами, заснований на шлюбі, відносинах родинності, усиновленні та інших підставах, передбачених у законі, який проявляється у наділенні їх на засадах рівності взаємними особистими немайновими та майновими сімейними правами та обов'язками, спільному житті, спільності інтересів та взаємній юридичній відповідальності» [7, с. 89].

Це, у свою чергу, ставить складне для правової системи завдання - виявити ті загальні вимоги правового регулювання сімейних відносин, виконання яких для держави є безумовним, і ті аспекти сімейного життя, в яких держава володіє певною свободою розсуду, необхідною їй для врахування «національної специфіки».

Для національної правової системи, яка визнає для себе обов'язковість практики Свропейського суду з прав людини (ст. 17 Закону України «Про виконання рішень та застосування практики Свропейського суду з прав людини» від 23.02.2006 р. № 3477-IV [8]), вирішення питання про належні стандарти врегулювання сімейних правовідносин не може відбуватися поза аналізом таких правових позицій вказаної інституції.

У цьому сенсі найбілыший інтерес становить практика застосування ст. 8 Конвенції про захист прав людини і основоположних свобод (далі - Конвенція). Нею, зокрема, передбачено право кожного на повагу його особистого і сімейного життя. Крім того, відповідно до ч. 2 ст. 8 Конвенції не допускається втручання з боку публічних властей у здійснення цього права, за винятком випадків, коли таке втручання передбачено законом і є необхідним у демократичному суспільстві в інтересах національної безпеки і громадського порядку, економічного благоустрою країни, в цілях попередження безпорядків або злочинів, для охорони здоров'я або моральності або захисту прав і свобод інших осіб [9].

Стаття 8 Конвенції гарантує також «приватне життя» в широкому сенсі цього виразу, включаючи право вести «приватне соціальне життя», тобто можливість для індивідуума розвивати свою соціальну ідентичність. У цьому аспекті вказане право включає можливість звернення до інших для того, щоб встановлювати і розвивати відносини із собі подібними (справа «Кампаньяно проти Італії) [10].

Серед правових позицій Свропейського суду з прав людини (далі - Суд), які визначають його практику у вирішенні справ, 
пов'язаних із захистом сімейних відносин, слід назвати такі:

1. Поняття сім'ї у значенні ст. 8 Конвенції включає в себе не тільки зареєстровані подружні відносини, але й інші «сімейні» зв'язки, які передбачають, що їх учасники живуть спільно поза законним шлюбом (наприклад, рішення у справі «Шальк і Копф проти Австрії» (Schalk and Kopf v. Austria) від 22 листопада 2010 р.) [20].

У своій практиці Суд здебільшого виходить із розуміння поняття сім'ї у значенні «сімейне життя», яке обмежується core family (рішення у справі «Маркс проти Бельгіï» (Marckx v. Belgium) від 13 червня 1979 р.) [21].

Під необхідністю втручання в сімейне життя мається на увазі, що воно (втручання) відповідає нагальній соціальній потребі i, зокрема, $€$ пропорційним до поставленої «законної» мети (рішення у справі «Кутцнер проти Німеччини» [13], п. 60, та рішення від 18 грудня 2008 р. у справі «Савіни проти України» (Saviny v. Ukraine), заява № 39948/06, п. 47) [12].

2. Професійне життя, будучи частиною зони взаємодії одних індивідуумів з іншими, навіть у публічному контексті, може підпадати під поняття «приватне життя». Саме в рамках своєї роботи більшість людей мають можливість зміцнювати безліч, тобто максимум, своїх зв’язків із зовнішнім світом (див. постанову Свропейського Суду у справі від 16 грудня 1992 г. «Німіц проти Германії» [Niemietz c. Allemagne], § 29, серія «A» [14]).

3. Захист інформації, отриманої з відстеження приватного використання мережі Інтернет. Відповідно до практики Суду телефонні дзвінки 3 ділових приміщень та кореспонденції у приватних цілях охоплюються поняттями приватного життя за ч. 1 ст. 8 Конвенції (справа «Halford проти Сполученого Королівства» від 25.06.1997 р. $\S 44$ та рішення Суду у складі Великої палати у справі «Amann проти Швейцарії» (справа № 27798/95, § 43 ECHR 2000-II) [15]).

4. Наявність або відсутність «сімейного життя», по суті, є питанням факту, що залежить від реального існування на практиці близьких особистих зв'язків, які можуть зна- ходити прояв, зокрема, у виявленні інтересу і визнанні батьком дитини до і після народження (рішення у справі «Леббінк проти Нідерландів» (Lebbink v. Netherlands) від 1 червня 2004 р.) [22].

5. Дитина, народжена від шлюбних відносин, згідно із самими законом, є частиною «сім'і» з моменту її народження і у зв'язку 3 ним (рішення у справі «Беррехаб проти Нідерландів» (Berrehab v. Netherlands) від 21 червня 1988 р.) [23]. Таким чином, між дитиною та її батьками існує зв'язок, що $€$ складовою частиною сімейного життя Цей зв'язок наступні події можуть розірвати тільки за надзвичайних обставин (рішення у справі «Гюль проти Швейцарії (Gül v. Switzerland) від 19 лютого 1996 р.) [24].

Інтерес дитини складається з двох аспектів. 3 одного боку, цей інтерес вимагає, що зв'язки дитини з їі сім'єю мають бути збережені, за винятком випадків, коли сім'я виявилася особливо непридатною. Звідси випливає, що сімейні зв'язки можуть бути розірвані лише у виняткових випадках та що необхідно зробити все, щоб зберегти особисті відносини й, якщо і коли це можливо, «відновити» сім'ю [рішення у справі «Гнахоре проти Франції» (Gnahore v. France) [16].

Судвстановлює, що позитивний обов'язок держави за статтею 8 Конвенції включае в себе право батьків на доступ до засобів, що дають їм можливість возз'єднатися з їхніми дітьми, та обов'язок національних органів вживати таких засобів. Проте обов'язок національних органів вживати таких засобів не є абсолютним. Якщо контакти з одним із батьків можуть виявитися такими, що загрожують цим інтересам або порушують ці права, саме національні органи забезпечують справедливий баланс між ними (рішення від 24 квітня 2003 року у справі «Зильвестер проти Австрії», заяви № 36812/97 та N 40104/98, п. 58[11]).

6. Стаття 8 Конвенції перш за все встановлює негативний обов’язок держави не втручатися до сфери сімейного життя людини, окрім обмеженого числа випадків, коли таке втручання спрямовано на досягнення легітимної мети, передбачено законом і обсяг

${ }^{1}$ Конституційний Суд України, даючи офіційне тлумачення частин першої, другої статті 32 Конституції України, вважає, що інформація про особисте та сімейне життя особи (персональні дані про неї) - це будьякі відомості чи сукупність відомостей про фізичну особу, яка ідентифікована або може бути конкретно ідентифікована, а саме: національність, освіта, сімейний стан, релігійні переконання, стан здоров'я, матеріальний стан, адреса, дата і місце народження, місце проживання та перебування тощо, дані про особисті майнові та немайнові відносини цієї особи з іншими особами, зокрема членами сім'ї, а також відомості про події та явища, що відбувалися або відбуваються у побутовому, інтимному, товариському, професійному, діловому та інших сферах життя особи, за винятком даних стосовно виконання повноважень особою, яка обіймає посаду, пов'язану зі здійсненням функцій держави або органів місцевого самоврядування. Така інформація про фізичну особу та членів її сім'ї є конфіденційною і може бути поширена тільки за їхньою згодою, крім випадків, визначених законом, і лише в інтересах національної безпеки, економічного добробуту та прав людини (http://ccu.gov.ua/storinka-knygy/429-pravo-na-nedotorkannist-simeynogo-zhyttya). 
втручання є сумірним тій меті, з якою воно здійснюється (заборона свавільного втручання держави) (рішення у справі «Ферліре проти Швейцарії» (Verliere v. Switzerland) від 28 червня 2001 р.) [25].

У справах, пов'язаних з виконанням рішень у сфері сімейного права, Суд неодноразово встановлював, що вирішальним $€$ те, чи вжили національні органи усіх необхідних для сприяння виконанню заходів, що можуть обгрунтовано вимагатися за особливих обставин кожної справи. Суд вважає, що позитивні обов'язки, які стаття 8 Конвенції накладає на Договірні держави щодо возз'єднання батьків з їхніми дітьми, повинні тлумачитися 3 урахуванням Гаазької Конвенції про цивільно-правові аспекти міжнародного викрадення дітей від 25 жовтня 1980 року (рішення у справі «ГгнакколоЗеніде проти Румунії», п. 95 [17]), а поняття «найкращі інтереси» дитини також є першорядним міркуванням у контексті процедур, передбачених Гаазькою Конвенцією (рішення у справі «Нойлінгер та Шурук проти Швейцарії» [ВП], заява № 41615/07, п. 76, ECHR 2010 [18]).

7. Однак, окрім основного негативного зобов'язання, у держави можуть виникати позитивні зобов'язання, які є необхідними для ефективного забезпечення поваги приватного або сімейного життя. Такі зобов'язання можуть включати застосування заходів, спрямованих на забезпечення поваги приватного життя навіть у сфері взаємин осіб між собою (mutatis mutandis, рішення у справі «X і Y проти Нідерландів» (X and $\mathrm{Y}$ v. Netherlands) від 26 березня 1985 р. [26]; рішення у справі «Ст'єрна проти Фінляндії» (Stjerna v. Finland) від 25 листопада 1994 р. [27]; рішення у справі «Ферліре проти Швейцарії» (Verliere v. Switzerland) від 28 червня 2001 p. [28]).

Неможливо точно визначити межу між відповідними позитивними і негативними зобов'язаннями держави. Застосовувані принципи тим не менше $є$ схожими. В обох випадках слід враховувати ту справедливу рівновагу, яку необхідно встановити між конкуруючими інтересами особи і суспільства в цілому, і в обох випадках держава має певні межі розсуду (рішення у справі «Кіган проти Ірландіï» (Keegan v. Ireland) від 26 травня 1994 р. [29], рішення у справі «Ботта проти Італії» (Botta v Italy) від 24 лютого 1998 р. [30], рішення у справі «Фон Ганновер проти Німеччини» (Von Hannover v. Germany) від 24 вересня $2004 \mathrm{p}$ [31]).

8. Приватний вибір жінок щодо планування і складу їхніх сімей не повинен залежати від розсуду медичних фахівців або установ, які визначають розподіл ресурсів охорони здоров'я або прагнуть просувати норми для статей, що засновані на релігійних або культурних ідеологіях, шляхом відмови у доступних діагностичних послугах з метою перешкоджання вчиненню дій, не схвалюваних ними. Жіноче право людини контролювати власне тіло зачіпає її здатність служити своїм родинам, включаючи неповнолітніх дітей та людей похилого віку, які залежать від такої жінки. Модель і склад сімейного життя жінок, включаючи розподіл ресурсів часу та енергії між здоровими і хворими дітьми та старшими членами родини, є питаннями глибокого особистого та емоційного значення (рішення у справі R.R. проти Польщі («R.R. v. Poland) від 26 травня 2011 р. [19]).

9. Стаття 8 Конвенції не покладає загального зобов'язання на державу поважати вибір іммігрантами країни свого перебування і санкціонувати возз'єднання сімей на своїй території. Тим не менше у справах, які стосуються сімейного життя й імміграції, обсяг обов'язків держави допустити родичів осіб, що перебувають на її території, буде залежати від конкретних обставин і загального інтересу (рішення у справі «Гюль проти Швейцарії» (Gül v. Switzerland) від 19 лютого 1996 р. [32], рішення у справі «Родрігес да Сілва і Хогкамер проти Нідерландів» (Rodrigues da Silva and Hoogkamer v. Netherlands) від 31 січня 2006 р. [33]). До факторів, які має бути враховано у цьому зв'язку, належить рівень порушення сімейного життя, рівень зв'язків у державі-учасниці, наявність/відсутність непереборних перепон для проживання сім'ї в рідній країні для одного чи більше її членів, наявність/відсутність там факторів імміграційного контролю (наприклад, випадки порушення імміграційного законодавства) або мотивів захисту суспільного порядку, які свідчать на користь винятку (рішення у справі «Родрігес да Сілва і Хогкамер проти Нідерландів» (Rodrigues da Silva and Hoogkamer v. Netherlands) від 31 січня 2006 р. [33], рішення у справі «Аджаі та інші проти Сполученого Королівства (Ајауі and Others v. United Kingdom) від 22 червня 1999 р. [11], рішення у справі «Соломон проти Нідерландів» (Solomon v. Netherlands) від 5 вересня 2000 p. [34]).

Важливим фактором може стати питання, чи почалося сімейне життя після того, як конкретних осіб було попереджено про те, що імміграційний статус одного з них робив збереження сімейного життя в приймаючій країні із самого початку ризикованим (рішення у справі «Джеррі Оладжиде Сарумі проти Сполученого Королівства» (Jerry Olajide Sarumi v. United Kingdom) від 26 січня 
1999 р. [35], рішення у справі «Андрій Шебашов проти Латвії (Andrey Sheabashov v. Latvia) від 22 травня 1999 р. [11]., рішення у справі «Дарен Оморегі та інші проти Норвегiï» (Darren Omoregie and Others v. Norway) від 31 липня 2008 р. [36]). Також Суд буде враховувати тривалість перебування заявника в країні, з якої він підлягає висилці; час, що минув після вчинення порушення, і поведінку заявника в цей період; громадянство заінтересованих осіб; сімейну ситуацію заявника, зокрема тривалість шлюбу та інші фактори, що відображають реальність сімейного життя пари; чи знав інший з подружжя про порушення в момент створення сімейних відносин; чи є діти від шлюбу і якщо так, скільки їх; серйозність складнощів, з якими імовірно зіткнеться людина в країні, в яку вона має бути вислана (рішення у справі «Бультиф проти Швейцарії» (Boultif v. Switzerland) від 2 серпня 2001 р. [37]).

10. Усиновлення одностатевими парами. Це одне $з$ найбільш дискусійних питань на новітньому етапі розвитку прецедентної практики Європейського суду з прав людини у сфері сімейно-правових відносин.

Так, в одній зі справ заявники стверджували, що їхня ситуація певною мірою схожа на ситуацію різностатевих пар, які виховують дітей. Вони послалися на результати численних наукових досліджень, які підтверджують той факт, що розвиток дітей у сім'ях 3 одностатевими батьками відбувається з таким самим успіхом, що й у сім'ях з батьками різної статі. Заявники також послалися на те, що можливість внутрішньосімейного усиновлення передбачена для подружніх пар. Згідно із законодавством державиучасниці, яка визнає можливість державної реєстрації партнерства одностатевих пар, водночас одностатевим парам не дозволено укладати шлюб. Навіть якщо вони зареєструють своє партнерство, вони все одно не матимуть права на внутрішньосімейне усиновлення, про що конкретно зазначено в пункті 4 статті 8 закону про зареєстроване партнерство. Заявники наголосили, що ключовим питанням в їхній справі є відмінність у ставленні до неодружених різностатевих пар і неодружених одностатевих пар. Згідно з практикою Суду саме Уряд має довести, що ненадання одностатевим парам права на внутрішньосімейне усиновлення $є$ необхідним для досягнення «законної» мети.

Свої доводи заявники також обгрунтували положеннями Свропейської Конвенції про усиновлення дітей 2008 року [38], Рекомендації Комітету міністрів Ради Європи від 31 березня 2010 року [39] та Конвенції ООН про права дитини [40, с. 205]. У всіх цих документах ключовим принципом щодо усиновлення є врахування найкращих інтересів дитини, а не гендерної чи сексуальної орієнтації батьків.

Суд вже розглядав ряд справ, у яких йшлося про дискримінацію за ознакою сексуальної орієнтації у сфері приватного та сімейного життя. Деякі 3 них розглядалися лише за статтею 8 Конвенції про захист прав людини і основоположних свобод; це були справи, які стосувалися встановленої кримінальним законом заборони гомосексуальних відносин між дорослими (див. рішення у справах: Dudgeon проти Сполученого Королівства від 22 жовтня 1981 р. [41]; Norris проти Ірландії від 26 жовтня 1988 р. [42]. Інші справи розглядалися за статтею 14 Конвенції про захист прав людини і основоположних свобод, взятою у поєднанні зі статтею 8. Порушені питання включали, зокрема, питання, пов'язані 3 передбаченою кримінальним законом відмінністю щодо віку сексуальної згоди для гомосексуальних відносин (див. L. i V. проти Австрії [43]) та наданням батьківських прав (див. рішення у справі Salgueiro da Silva Mouta [44]), дозволу на усиновлення дитини (рішення у справах Fretté, Е.В. проти Франції [45] та Gas i Dubois проти Франції [389]), можливістю для одностатевих пар укладати шлюб або мати альтернативну форму юридично визнаного сімейного союзу (див. рішення у справі Schalk i Kopf [46]).

У розглядуваній справі Суд знову повторив, що відносини між співмешканцями в одностатевій парі, які перебувають у де-факто існуючих постійних стосунках, так само як і відносини в різностатевій парі в такій самій ситуації, підпадають під визначення «сімейне життя» (рішення у справі Schalk i Kopf [46]) Суд зазначив, що в разі, якщо підстави, якими мотивується відмінність у ставленні, пов'язані виключно з урахуванням сексуальної орієнтації заявниці, такий підхід вважатиметься, з точки зору Конвенції про захист прав людини і основоположних свобод, дискримінаційним. Отже, Суд констатував порушення статті 14, взятої у поєднанні зі статтею 8 Конвенції про захист прав людини і основоположних свобод.

\section{Висновки}

На підставі викладеного вище ми можемо зробити такі висновки, шо мають враховуватися під час визначення основних напрямів розвитку української національної правової системи у сфері правового регулювання сімейних відносин:

- поняття «сімейного життя» постійно еволюціонувало упродовж усього часу і про- 
довжує розвиватися с урахуванням сучасних змін соціальних і культурних моделей сімейного життя;

- Суд застосовує гнучкий підхід до інтерпретації сімейного життя, беручи до уваги різноманітність сімейних взаємин, можливість розлучення і досягнення медицини;

- сімейне життя включено безпосередньо до сфери особистого життя, де йому забезпечується право вільного від свавільного втручання держави існування;

- Суд вирішує питання про наявність «сімейного життя» на основі фактів, які розглядаються в кожному конкретному випадку, і загального застосовуваного принципу про існування тісних особистих зв'язків між учасниками сімейних відносин;

- у низці розглядуваних Судом справ простежується конфлікт між обмежувальною концепцією сім’ї (що відома правовій антропології як «нуклеарна сім'я») і традицією «розширення сім’ї», що особливо сильною є в країнах Східної і Південної Свропи. У цих країнах традиція допомагати батькам похилого віку міцно утвердилася як моральний імператив. «Сімейне життя» для них $є$ очевидно немислимим без можливості піклуватися про родичів за висхідною лінією (окрема думка судді Ковлера у справі «Сліденко проти Латвії» (Slidenko v. Latvia) від 9 жовтня 2003 р. [11]).

Згідно зі статтею 8 Конвенції, вона має на меті захистити індивідуума від свавільного втручання органів державної влади у здійснення ним своїх прав. Згідно 3 пунктом 2 статті 8 Конвенції, таке втручання повинно бути «передбачено законом» і виправдано необхідністю досягнення законної мети або цілей (див. Постанову Свропейського Суду від 23 березня 2006 р. у справі «Вітьелло проти Італії» ([Vitiello c. Italie] (ск. № 77962/01), § 51) [11, с. 39].

Сучасне розуміння поняття «сімейне життя» Конвенцією включає більш багатоаспектну конструкцію сімейного життя, безумовно, враховуючи поняття «сім'я», найрізноманітніші суспільні процеси, від міграції до новітніх медичних технологій. 3 урахуванням специфіки сімейних прав, гарантованих ст. 8 Конвенції, у врегулюванні юридичних фактів у сімейно-правовій сфері мають враховуватися межі державного впливу на відносини, що складаються в сім'ї, а також дотримуватися баланс у нормуванні загально-правових відносин та приватних сімейних відносин особистого характеру, які взагалі не повинні регулюватися законом або мають піддаватися мінімальному нормативному впливу.

\section{Список використаних джерел:}

1. Сафончик O.I. Правове регулювання припинення шлюбу в Україні : автореф. дис. ... канд. юрид. наук: 12.00.03. Одеса, 2004. 20 с.

2. Сімейно-побутова культура та домашня економіка : навчальний посібник / за ред. Т.Б. Гриценко, Т.Д. Іщенко, Т.Ф. Мельничек. Київ : Вища освіта, 2004. 480 c.

3. Харчев А. Г. Брак и семья в СССР. Москва : Изд-во Мысль, 1979. 367 с.

4. Шимин Н. Д. Семья как общественное явление : Опыт социально-философского анализа. Воронеж : Изд-во Воронеж. ун-та, 1989. 188 с.

5. Рясенцев В. А. Семейное право. Москва : Юридическая литература, 1971. 293 с.

6. Шершеневич Г. Ф. Учебник русского гражданского права (по изданию 1907 г.). Москва : СПАРК, 1995. $556 \mathrm{c}$.

7. Ватрас В.А. Поняття «Сім'ї» у сімейному праві України. Форум права. Харьков. 2009. № 1. C. 83-91. URL : http://univer.km.ua/statti/ 1.vatras_v.a._ponyattya_sim_yi_u_simeynomu_ pravi ukrayiny.pdf (дата звернення: 02.08.2019).

8. Про виконання рішень та застосування практики Європейського суду 3 прав людини : Закон України від 23.02.2006 № 3477-IV. Офіиійний вісник України. 2006. № 12. С. 16. С. 792.

9. Конвенція про захист прав людини і основоположних свобод : ратифіковано Законом України від 17.07.97 № 475/97-BP. URL : (дата звернення: 22.08.2019)

10. Постанова Європейського Суду у справі «Кампаньяно проти Італії» ([Campagnano c. Italie] (скарга № 77955/01), § 53. Збірник постанов і рімень Європейського Суду з прав людини [CEDH] 2006-V). URL : http://nsj.gov.ua/files/ 15296531171517493.....1\%82.pdf (дата звернення: 02.08.2019).

11. Збірник витягів 3 рішень Європейського суду з прав людини, рекомендованих для вивчення при підготовці до письмового анонімного тестування у межах іспиту для кваліфікаційного оцінювання суддів на відповідність займаній посаді від 1 січня 2018 p. URL : http://nsj.gov. ua/files/ 1529653117151749398........\%82.pdf (дата звернення: 02.08.2019).

12. Рішення Європейського суду 3 прав людини у справі "Савіни проти України" (Заява № 39948/06), Страсбург, 18 грудня 2008 року. URL : https://zakon.rada.gov.ua/laws/ show/974_454 (дата звернення: 02.07.2019).

13. Рішення Європейського суду 3 прав людини у справі "Кутцнер проти Німеччини" (заява № 46544/99), Страсбург, 26 лютого 2002 року. URL : (дата звернення: 02.07.2019).

14. Постановление Европейского Суда по правам человека «Нимитц против Германии» (Niemietz v. Germany): (жалоба № 13710/88), Страсбург, 16 декабря 1992 года. URL : http:// europeancourt.ru/resheniya-evropejskogo-sudana-russkom-yazyke/nimitc-protiv-germaniipostanovlenie-evropejskogo-suda/ (дата звернення: 02.07.2019). 
15. Рішення Європейського суду з прав людини у справі «АМАНН ПРОТИ ШВЕЙЦАPIÏ» (CASE OF AMANN v. SWITZERLAND) (Заява № 27798/95), Страсбург, 16 лютого 2000 року. URL : http://eurocourt.in.ua/Article. asp?AIdx=308 (дата звернення: 02.07.2019).

16. Рішення Європейського суду 3 прав людини у справі «Гнахоре проти Франції» (Gnahore v. France), Страсбург, 2001 рік. URL : http://www.shatarska.in.ua/9-pravo-na-povagu-doprivatnogo-i-simejnogo-zhittya-privesti-prikladrishennya-yespl-v-konkretnij-spravi (дата звернення: 02.08.2019)

17. Рішення Європейського суду з прав людини у справі «Ггнакколо-Зеніде проти Румунії» (Ignaccolo-Zenide v. Romania), (заява № 31679/96, пункт 94, ЄСПЛ2000-I). URL : https://zakon. rada.gov.ua/laws/show/974_c.87 (дата звернення: 02.08.2019).

18. Рішення Європейського суду з прав людини у справі «Нойлінгер і Шурук проти Швейцаріï» [ВП] (Neulinger and Shuruk v. Switzerland) [GC], (заява № 41615/07, пункт 76,135, ЄСПЛ 2010). URL : https://zakon.rada.gov.ua/laws/ show/974_d46 (дата звернення: 12.08.2019).

19. Постановление Европейского Суда по правам человека по делу R.R. против Польши (R.R. v. Poland) (Жалоба № 27617/04 от 26 мая 2011 г.). Избранныепостановления европейского суда. Спеииальный выпуск № 2/2012. URL : file://C:/Users/Comp/ Downloads/001-116212.pdf (дата звернення: 12.08.2019).

20. Рішення Європейського Суду з прав людини у справі «Шальк і Копф проти Австрії» (Schalk and Kopf v. Austria) від 22.11.2010 p. URL : http://hudoc.echr.coe.int/sites/ eng/pages/search.aspx?i=001-99605. (дата звернення: 12.08.2019)

21. Рішення Європейського Суду з прав людини у справі «Маркс проти Бельгіі» (Marckx v Belgium) від 13.06.1979 p. URL: http://hudoc.echr. coe.int/sites/eng/pages/search.aspx?i=001-57534. (дата звернення: 12.08.2019)

22. Рішення Європейського Суду з прав людини у справі «Леббінк проти Нідерландів» (Lebbink v. Netherlands) від 01.06.2004 р. URL : http://www.amen.ie/downloads/26033.pdf (дата звернення: 02.08.2019).

23. Рішення Європейського Суду 3 прав людини у справі «X,Y and $\mathrm{Z}$ v. United Kingdom». URL : http://www.echr.ru/documents/decisions. htm. (дата звернення: 02.08.2019).

24. Рішення Європейського Суду 3 прав людини у справі «Гюль проти Швейцарії» (Gül v. Switzerland) від 19.02.1996 p. URL : http://hudoc.echr.coe.int/sites/ eng/pages/search.aspx?i=001-57975. (дата звернення: 15.08.2019)

25. Рішення Європейського Судузправлюдини у справі «Ферліре проти Швейцарії» (Verliere v. Switzerland) від 28.06.2001 p. URL : http://caselaw. echr.globe24h.com/0/0/switzerland/2001/06/28/ verliere-v-switzerland-22587-41953-98.shtml (дата звернення: 15.08.2019)

26. Рішення Європейського Суду 3 прав людини у справі «X і Y проти Нідерландів» (X and Y v. Netherlands) від 26.03.1985 p. URL : http://hudoc.echr.coe.int/sites/ eng/pages/search.aspx?i=001-57603. (дата звернення: 15.08.2019).

27. Рішення Європейського Судузправлюдини у справі «Ст'єрна проти Фінляндії» (Stjerna v. Finland) від 25.11.1994 p. URL : http://hudoc.echr. coe.int/sites/eng/pages/search.aspx?i=001-57912. (дата звернення: 15.08.2019).

28. Рішення Європейського Судузправлюдини у справі «Ферліре проти Швейцарії (Verliere v. Switzerland) від 28.06.2001 p. URL : http://caselaw. echr.globe24h.com/0/0/switzerland/2001/06/28/ verliere-v-switzerland-22587-41953-98.shtml (дата звернення: 15.08.2019).

29. Рішення Європейського Суду 3 прав людини у справі «Кіган проти Ірландії» (Keegan v Ireland) від 26.05.1994 p. URL : http://hudoc.echr. coe.int/sites/eng/pages/search.aspx?i=001-57881. (дата звернення: 15.08.2019).

30. Рішення Європейського Суду з прав людини у справі «Ботта проти Італії» (Botta v Italy) від 24.02.1998 p. URL : http://hudoc.echr. coe.int/sites/eng/pages/search.aspx?i=001-58140. (дата звернення: 02.08.2019).

31. Рішення Європейського Суду з прав людини у справі «Фон Ганновер проти Німеччини» (Von Hannover v. Germany) від 24.09.2004 p. URL : http://hudoc.echr.coe.int/sites/ eng/pages/search.aspx?i=001-109029. (дата звернення: 02.08.2019).

32. Рішення Європейського Суду 3 прав людини у справі «Гюль проти Швейцарії (Gül v. Switzerland) від 19.02.1996 p. URL : http://hudoc.echr.coe.int/sites/ eng/pages/search.aspx?i=001-57975. (дата звернення: 02.08.2019).

33. Рішення Європейського Суду з прав людини у справі «Родрігес да Сілва і Хогкамер проти Нідерландів» (Rodrigues da Silva and Hoogkamer v. Netherlands) від 31.01.2006 p. URL : http://hudoc.echr. coe.int/ sites/eng/pages/search.aspx?i=001-72205. (дата звернення: 12.08.2019).

34. Рішення Європейського Суду 3 прав людини у справі «Соломон проти Нідерландів» (Solomon v. Netherlands) від 05.09.2000 p. URL : http://caselaw.echr.globe24h. com/0/0/netherlands/2000/09/05/solomon-v-thenetherlands-5398-44328-98.shtml (дата звернення: 02.08.2019).

35. Рішення Європейського Суду з прав людини у справі «Джеррі Оладжиде Сарумі проти Сполученого Королівства» (Jerry Olajide Sarumi v. United Kingdom) від 26.01.1999 p. URL : http:// www.refworld.org/ docid/3ae6b74a0.html (дата звернення: 12.08.2019).

36. Рішення Європейського Суду з прав людини у справі «Дарен Оморегі та інші проти 
Норвегіï» (Darren Omoregie and Others v. Norway) від 31.07.2008 p. URL : http://hudoc.echr.coe.int/ sites/eng/pages/search.aspx?i=001-88012. (дата звернення: 02.08.2019).

37. Рішення Європейського Суду 3 прав людини у справі «Бультиф проти Швейцарії (Boultif v. Switzerland) від 02.08.2001 p. URL: http://hudoc.echr.coe.int/sites/ eng/pages/search.aspx?i=001-59621. (дата звернення: 02.08.2019).

38. Європейська Конвенціїя про усиновлення дітей 2008 року : ратифіковано Законом України № 3017-VI ( 3017-17 ) від 15.02.2011 із застереженням та заявою. URL : https://zakon.rada.gov.ua/ laws/show/994_a17 (дата звернення: 12.08.2019).

39. Рекомендація $\mathrm{CM} / \operatorname{Rec}(2010) 5$ Комітету Міністрів Ради Європи державам-членам про заходи з боротьби проти дискримінації за ознаками сексуальної орієнтації або гендерної ідентичності : ухвалена Комітетом Міністрів 31 березня 2010 року на 1081-ому засіданні представників міністрів. URL : http://www.insight-ukraine.org/ cmrec20105/ (дата звернення: 02.08.2019).

40. Конвенція Організації Об'єднаних Націй про права дитини. URL : http://zakon5.rada. gov.ua/laws/show/995_021. (дата звернення: 02.08.2019).
41. Рішення Європейського суду 3 прав людини у справі «Dudgeon v. The United Kingdom». URL : http://hudoc.echr.coe.int/eng?i=001-57473. (дата звернення: 12.08.2019).

42. Рішення Європейського суду з прав людини у справі «L. and V. v. Austria». URL : http://hudoc.echr. coe.int/eng?i=001-60876. (датазвернення: 02.08.2019).

43. Рішення Європейського суду 3 прав людини у справі «Лінгенс проти Австрії» (Lingens v. Austria), Страсбург 8 липня 1986 року. https://cedem.org.ua/library/sprava-lingens-protyavstriyi/ (дата звернення: 15.08.2019).

44. Рішення Європейського Суду з прав людини у справі «Salgueiro da Silva Mouta проти Португалії» («Salgueiro da Silva Mouta v. Portugal»). URL : http://hudoc.echr.coe.int/ eng?i=001-58404. (дата звернення: 15.08.2019).

45. Рішення Європейського Суду 3 прав людини у справі «Фретте проти Франції» («Frette v. France»). URL : http://hudoc.echr.coe.int/ eng?i=001-60168 (дата звернення: 02.08.2019).

46. Рішення Європейського Суду з прав людини у справі «Шальк і Копф проти Австрії» (Schalk and Kopf v. Austria) від 22.11.2010 p. URL : http://hudoc.echr.coe.int/sites/ eng/pages/search.aspx?i=001-99605. (дата звернення: 02.08.2019).

The article provides a scientific and theoretical analysis of the content of the concept of "family" in legal science, presents a comparative analysis of the concept of "family" taking into account the specifics of family and marriage relations. The author believes that the issue of appropriate standards for the settlement of family legal relations cannot be resolved outside the analysis of the legal positions of the European Court of Human Rights.In its practice, the Court mainly proceeds from an understanding of the concept of the family in the meaning of "family life", which is limited to the core family. The article states that the concept of the family in the sense of Art. 8 of the Convention includes not only registered marital relations, but also other "family" relations, which stipulate that their participants live together outside a legal marriage and they also have family rights and obligations, as in a registered marriage. Based on an analysis of the case-law of the European Court of Human Rights, the author identifies his main legal positions, which play the most significant role in resolving cases related to the application of Art. 8 of the Convention for the Protection of Rights and Fundamental Freedoms. The author concludes that the modern understanding of the concept of "family life" of the Convention includes a more multifaceted design of "family life", of course, given the concept of "family", the most social processes, from migration to the latest medical technologies. Author on the basis of the analysis of the case law of the European Court of Human Rights releases its basic legal positions that play the most significant role in cases relating to the application of Art. 8 of the Convention for the Protection of Human Rights and Fundamental Freedoms. The above analysis leads to the conclusions that should be considered when determining the main directions of development of the national legal system in the sphere of legal regulation of family relations.

Key words: family, family life, family contacts, positive obligations of the state, negative obligation of the state. 